\title{
Identifying competitive strategies to improve the performance of hospitals in a competitive environment
}

\author{
Chuan-Hui Chang ${ }^{1,2}$, Yu-Ching Chiao ${ }^{1}$ and Yafang Tsai ${ }^{3,4^{*}}$ (D)
}

\begin{abstract}
Background: This study is based on competitive dynamics theory, and discusses competitive actions (including their implementation requirements, strategic orientation, and action complexity) that influence hospitals' performance, while also meeting the requirements of Taiwan's "global budget" insurance payment policy.

Methods: In order to investigate the possible actions of hospitals, the study was conducted in two stages. The first stage investigated the actions of hospitals from March 1 to May 31, 2009. Semi-structured questionnaires were used, which included in-depth interviews with senior supervisors of 10 medium- and large-scale hospitals in central Taiwan. This stage collected data related to the types of actions adopted by the hospitals in previous years. The second stage was based on the data collected from the first stage and on developed questionnaires, which were distributed from June 29 to November 1, 2009. The questionnaires were given to 20 superintendents, deputy superintendents, and supervisors responsible for the management of a hospital, and focused on medical centers and regional hospitals in central Taiwan in order to determine the types and number of competitive actions.
\end{abstract}

Results: First, the strategic orientation of an action has a significantly positive influence on subjective performance. Second, action complexity has a significantly positive influence on the subjective and the objective performance of a hospital. Third, the implementation requirements of actions do not have a significantly positive impact on the subjective or the objective performance of a hospital.

Conclusion: Managers facing a competitive healthcare environment should adopt competitive strategies to improve the performance of the hospital.

Keywords: Competitive dynamics, National health insurance, Global budget system, Type of hospital action, Performance

\section{Background}

Subsequent to the establishment of the National Health Insurance (NHI) system, Taiwan's National Health Insurance Administration (NHIA) faced financial pressure due to increasing medical expenses. In 2002, it implemented a healthcare insurance payment policy called the "global budget," which replaced the existing "fee-for-service" policy. The purpose of the global budget policy was to control the expenses of the entire medical care reimbursement system. However, in order to secure a portion of the

\footnotetext{
*Correspondence: avon611@gmail.com

${ }^{3}$ Department of Health Policy and Management, Chung Shan Medical University, Taichung, Taiwan

${ }^{4}$ Department of Medical Management, Chung Shan Medical University Hospital, Taichung, Taiwan

Full list of author information is available at the end of the article
}

limited healthcare budget, the policy increased competition among hospitals within the same domain, prompting hospital managers to reform their operation models. These policy changes were successful in decelerating hospital revenues and expenditures [1]. Under these conditions, hospital managers face the challenge of taking appropriate competitive actions.

Therefore, this study explores the types of strategic orientation that need to be adopted and their effects on performance in hospitals in Taiwan that function within competitive environments. The research outcomes could assist in boosting the confidence of hospital managers. Previous studies on competitive strategies have generally used either a static 
analysis [2] or the Herfindahl-Hirschman Index (HHI) [1, $3-5]$. This study is based on competitive dynamics theory, and explores the competitive actions (including their strategic orientation, action complexity, and implementation requirements) that influence hospitals' performance, while meeting the requirements of Taiwan's global budget insurance payment policy.

\section{Perspective of awareness-motivation-capability (AMC)}

When organizations function in a market environment with competitive dynamics, they should adopt strategies based on the changes occurring in the market. For instance, organizations change their strategies after observing other competitors in the market. Chen et al. [6] extended the AMC theory, where responses (stimulations) to competitive actions are initiated only when rivals become aware of the competitive move and they possess the motivation and capability to respond. In contrast, when facing a strategic or challenging competitive move, the likelihood of initiating a response is minimal in the case of low capability [7]. The AMC perspective proposes that a firm will respond to a stimulation only when it is aware of the action and is motivated to respond [8].

\section{Characteristics of competitor actions}

From an AMC perspective, before initiating an action or a response, an organization or a rival needs to become aware of the actions of the competitor, as well as the changes occurring in the organization's external environment. Awareness is essentially consciousness, and motivation is a combination of psychological and cognitive phenomena [9]. A "strategic orientation" affects the likelihood of an attack on other competitors. Here, a rival should consider the "action complexity" and the "implementation requirements" before responding with the motivation necessary to achieve the expected result.

\section{Implementation requirement of an action}

Implementation requirements refer to the effort that an initiator devotes to an action-an extreme promise index for an attack-because an organizational promise and implementation requirements are essential for coordinating a competitive action [10]. Therefore, implementation requirements describe the type of initiator and provide information on a competitive action promise [10]. In practice, there are multiple resources involved in the implementation requirements, including the economy, regulation, organization, psychology, and government precepts, all of which present the message on the type of action type for the attack [10]. Chen et al. [6] state that an attack with high implementation requirements reduces the number of competitive responses and increases their lag time. Most rivals are not willing to respond to a firm's attack, and the speed of their responses is generally low [6], which results in better performance of the attacking firm. Thus, a hospital will exhibit better performance when it undertakes actions with a higher implementation requirement.

\section{Strategic orientation of action}

In general, competitive action sends a specific message to the markets, which could be visible or implicit. Subsequently, other organizations will evaluate and manage this message in order to achieve success in the market [11]. Organization information processing theory examines the information flow inside and surrounding an organization in order to explain organizational behavior [12]. However, there are several types of competitive actions, with various messages, and each type is associated with a particular scope and cost. These strategic actions include competitive actions with significant investments in fixed assets, staff, and organizational structure change, or radical innovation to work around industry regulations [6], including equipment expansion, mergers and acquisitions, alliances, and introducing new products or services [13]. In contrast, tactical actions refer to the actions that do not have specific commitments to fixed assets, have less of an effect on the initiator in the long term [6], and have small and routine transformations that are mostly completed by lower-level managers using a minimum resource commitment. These actions can be managed by thoroughly revising current procedures and do not require serious structural adjustments [6], such as price cuts, advertisements, or gradual adjustments of products or services [13].

Broadly speaking, an organization's response to a strategic action could be vague and uncertain. This can be attributed to managers undertaking the majority of the decisions, or organizational information not translating external information into internal concepts through information processing [11]. In addition, time and energy are required to deal with such information. In order to achieve better efficiency, managers initiate strategic actions. However, because the information is often considerably uncertain, in order to minimize risks, they may wait to obtain clear information, and then subsequently decide whether to respond. Therefore, reduced responses lead to better performance in organizations that have a high strategic orientation toward action.

\section{Action complexity}

Considering the aspect of information processing and analysis mechanisms, information about external circumstances must be analyzed and transferred to the decisionmaker. However, if an organization does not have a specific system in place or a return path to the administrator for a response, the organization's response speed could decrease or be delayed [11]. In other words, the defender requires 
more information to support decision-making when they are unsure of the actual type of competition or the manner in which the initiator will defend their own benefit [10]. Therefore, when organizations initiate several types of competitive actions, a more competitors are less able to respond, which delays the speed of their responses, and decreases their capability and the resources they have available to respond. This can significantly improve the firm's performance $[14,15]$.

\section{Methods}

\section{Sample}

This study focuses on hospitals. Research on the industrial characteristics of hospitals occasionally focused on the subject of "competition" before the launch of the NHI. With the launch of the NHI and the start of the global budget system, hospitals felt competitive pressure. According to the Ministry of Health and Welfare (MHW), in August 2009, regional hospitals in central Taiwan with more than 250 general acute beds had 32.51 beds for every 10,000 individuals, which is higher than the average of 31.61 beds for regions around Taiwan. Thus, Chiang et al. [16] note that beds per capita figures can be viewed as proxy variables for competitive intensity. Therefore, regional hospitals in central Taiwan are more competitive. Between 2006 and 2008, the point value of the global budget for hospitals of central Taiwan was lower than the national average point value. The global budget payment system in Taiwan adopts an expenditure cap, which constrains rapid growth in costs. If the total amount claimed for reimbursement by a sector exceeds the preset ceiling, the point values (which determine the amount hospitals receive from the NHI per service provided) for that sector's services could drop.

This reveals the competitive pressure faced by hospitals in central Taiwan, particularly in the case of medium- and large-scale hospitals. Thus, this study focuses on the medical centers and regional hospitals (20 hospitals) in central Taiwan.

Semi-structured questionnaires were used to investigate the possible actions of hospitals from March 2009 to May 2009. This included in-depth interviews with superintendents, deputy superintendents, and assistants of superintendents of 10 medium- and large-scale hospitals in central Taiwan. Thus, this study collected data on previous actions adopted by the hospitals, such as developing cosmetic medicine services, paid for privately by customers, participating in community health-prevention programs, establishing common laboratories among hospitals, and forming joint medical procurement teams.

In order to avoid the classification of repetitive or incomplete types of actions, senior supervisors of two regional hospitals and one medical scholar (who was familiar with hospital operations) were invited to test and verify the content of the items. The senior supervisors provided suggestions (twice) to enhance the expert validity of this study. Finally, 21 types of general actions were identified, including price cutting/promotion and service improvement/enhancement (see Table 3).

\section{Data collection}

After reviewing previous studies on competitive dynamics, Smith et al. [17] suggested that data collection in research studies on actions and responses of high-technology (hightech) firms from 1985 to 1986, and on competitive responses of computer retailers in 1988 were all based on questionnaires. In addition to the interviews conducted to classify the actions, this study considered 20 medium- and large-scale hospitals, focusing on medical centers and regional hospitals in central Taiwan. Questionnaires were distributed to superintendents, deputy superintendents, and the supervisors responsible for the management of hospitals. The questionnaire included items of all competitive actions and perceptions of the hospital's performance for the previous three years (i.e., 2006, 2007, and 2008).

\section{Measures}

The definition and measurement of the independent variables are based on competitive dynamics theory. This study applies three independent variables as follows: implementation requirement of action $[10,6]$; strategic orientation of action [11, 6, 13]; and action complexity $[11,10,15,14]$.

Number of competitive action types adopted by hospitals Observing a yearly pattern, regional hospital $G$ has undertaken 20 types of actions, which is also the highest number of types of actions. Table 1 illustrates that medical center $C$ has undertaken the most number of actions (346). Considering action numbers, medical center $C$ and regional hospital $R$ undertook the most actions for 2006 and 2007, and for 2008, respectively. Regional hospital $I$ did not present any action type in 2006 because this was the year of its launch. However, the hospital began observable action types and numbers from 2007. Regional hospital $R$ is one of the most interesting hospitals because it has grown in terms of both types of actions and the number of actions, as compared with other hospitals. Thus, is worth investigating further in future research.

\section{Competitive actions}

Competitive actions refer to specific and detectable competitive moves [11], such as the procurement of high-tech equipment. The questionnaire lists possible items from 21 types of actions. The total number of competitive actions of the hospitals in each year are based on the number of items in the current year, as indicated by the hospitals. 
Table 1 The types and number of competitive actions in hospitals

\begin{tabular}{|c|c|c|c|c|c|c|c|c|c|}
\hline \multirow{2}{*}{$\begin{array}{l}\text { Names of } \\
\text { hospitals }\end{array}$} & \multicolumn{3}{|l|}{2006} & \multicolumn{3}{|l|}{2007} & \multicolumn{3}{|l|}{2008} \\
\hline & $\begin{array}{l}\text { Type of } \\
\text { action }^{\mathrm{a}}\end{array}$ & $\begin{array}{l}\text { Number of } \\
\text { actions }^{\text {b }}\end{array}$ & $\begin{array}{l}\text { Objective } \\
\text { performance }\end{array}$ & $\begin{array}{l}\text { Type of } \\
\text { action }\end{array}$ & $\begin{array}{l}\text { Number of } \\
\text { actions }\end{array}$ & $\begin{array}{l}\text { Objective } \\
\text { performance }\end{array}$ & $\begin{array}{l}\text { Type of } \\
\text { action }\end{array}$ & $\begin{array}{l}\text { Number of } \\
\text { actions }\end{array}$ & $\begin{array}{l}\text { Objective } \\
\text { performance }\end{array}$ \\
\hline $\begin{array}{l}\text { Medical } \\
\text { center A }\end{array}$ & 17 & 96 & 6266 & 17 & 96 & 6314 & 17 & 100 & 6606 \\
\hline $\begin{array}{l}\text { Medical } \\
\text { center B }\end{array}$ & 18 & 106 & 6656 & 18 & 115 & 7014 & 18 & 114 & 8096 \\
\hline $\begin{array}{l}\text { Medical } \\
\text { center C }\end{array}$ & 19 & 116 & 3308 & 18 & 113 & 3512 & 18 & 117 & 3574 \\
\hline $\begin{array}{l}\text { Medical } \\
\text { center D }\end{array}$ & 16 & 75 & 6606 & 16 & 77 & 6745 & 18 & 93 & 6977 \\
\hline $\begin{array}{l}\text { Regional } \\
\text { hospital E }\end{array}$ & 16 & 75 & 1025 & 17 & 85 & 1110 & 18 & 91 & 1232 \\
\hline $\begin{array}{l}\text { Regional } \\
\text { hospital F }\end{array}$ & 14 & 97 & 3141 & 15 & 94 & 3197 & 16 & 99 & 3215 \\
\hline $\begin{array}{l}\text { Regional } \\
\text { hospital G }\end{array}$ & 20 & 102 & 1410 & 20 & 110 & 1364 & 20 & 109 & 1395 \\
\hline $\begin{array}{l}\text { Regional } \\
\text { hospital H }\end{array}$ & 18 & 90 & 1617 & 18 & 94 & 1642 & 19 & 96 & 1657 \\
\hline $\begin{array}{l}\text { Regional } \\
\text { hospital I }\end{array}$ & 0 & 0 & 0 & 12 & 50 & 720 & 10 & 41 & 1107 \\
\hline $\begin{array}{l}\text { Regional } \\
\text { hospital J }\end{array}$ & 16 & 92 & 3251 & 17 & 98 & 3383 & 18 & 107 & 3403 \\
\hline $\begin{array}{l}\text { Regional } \\
\text { hospital K }\end{array}$ & 19 & 81 & 2831 & 19 & 100 & 2932 & 19 & 111 & 2951 \\
\hline $\begin{array}{l}\text { Regional } \\
\text { hospital L }\end{array}$ & 13 & 56 & 1574 & 14 & 62 & 1591 & 15 & 65 & 1688 \\
\hline $\begin{array}{l}\text { Regional } \\
\text { hospital M }\end{array}$ & 12 & 47 & 555 & 13 & 49 & 554 & 14 & 57 & 592 \\
\hline $\begin{array}{l}\text { Regional } \\
\text { hospital N }\end{array}$ & 16 & 69 & 989 & 17 & 98 & 1011 & 18 & 108 & 1013 \\
\hline $\begin{array}{l}\text { Regional } \\
\text { hospital O }\end{array}$ & 15 & 58 & 979 & 17 & 70 & 1219 & 18 & 78 & 1341 \\
\hline $\begin{array}{l}\text { Regional } \\
\text { hospital P }\end{array}$ & 17 & 82 & 2824 & 17 & 82 & 2773 & 18 & 84 & 3059 \\
\hline $\begin{array}{l}\text { Regional } \\
\text { hospital Q }\end{array}$ & 14 & 53 & 637 & 14 & 58 & 621 & 16 & 68 & 634 \\
\hline $\begin{array}{l}\text { Regional } \\
\text { hospital R }\end{array}$ & 13 & 57 & 302 & 15 & 103 & 1064 & 19 & 133 & 1424 \\
\hline $\begin{array}{l}\text { Regional } \\
\text { hospital S }\end{array}$ & 15 & 49 & 726 & 16 & 60 & 752 & 20 & 82 & 810 \\
\hline $\begin{array}{l}\text { Regional } \\
\text { hospital T }\end{array}$ & 11 & 36 & 535 & 15 & 53 & 540 & 15 & 56 & 567 \\
\hline Total of year & - & 1437 & & - & 1667 & & - & 1809 & \\
\hline
\end{tabular}

${ }^{a}$ The type of action meaning may be influenced by the competitive impact and the attack intensity of the action

${ }^{\mathrm{b}}$ The number of action means the action accumulation amount

'Objective performance means medical expenditures (i.e., outpatient service, hospitalization, dialysis, emergency treatment, etc.) from the NHI, which are applied by the hospitals every year on the NHIA website, and the unit is million points

${ }^{\mathrm{d}}$ This hospital was founded in December 2006 and thus, type of action and the number of action in the said year are 0

\section{Implementation requirements of action}

Based on the items in the questionnaire on action irreversibility designed by Chen and MacMillan [10], this study developed the "agreement with types of action" questionnaire, using a 5-point Likert scale (from "strongly disagree" to "strongly agree"), where each type included 12 items. The average scores of the hospitals are based on the scores of agreement with the 21 types of actions in each hospital, divided by 21 (types of actions), and divided again by 12 (items of each type). The 
formula for determining the implementation requirements score is as follows: $\mathrm{i} / 21 / 12=\sum_{i=1}^{21}$.

\section{Strategic orientation of action}

According to the results of the "agreement with types of actions" questionnaire, this study calculates the overall average of the hospital and the average of the execution conditions as 3.5694. When the score of the type of action is higher than the average of the overall implementation requirements, this is considered a strategically competitive action; when it is lower than the average, this is regarded as a tactically competitive action. Here, 11 types of actions revealed scores higher than the overall average of implementation requirements (strategic competitive actions). To measure the strategic orientation of actions, this study divided the total number of strategic competitive actions in the hospitals by the total number of their actions, and then multiplied this by the average of the overall implementation requirements.

\section{Action complexity}

This study multiplied the implementation requirement scores of the types of actions in one hospital by the total number of each actions in each year. A score higher than that of other hospitals means that the action had higher implementation requirements, and that the hospital was required to invest resources, which rivals struggled to compete with. The formula used was $\sum_{i=1}^{21}$ where the implementation requirements score for type of action $\mathrm{i}$ * denotes the number of actions $\mathrm{i}$.

\section{Hospital performance}

We include both objective and subjective performance in this study. Objective performance is measured in terms of annual medical expenditure (e.g., outpatient services, hospitalization, dialysis, emergency treatments, etc.) from the NHI, which hospitals apply every year based on the NHIA website [18]. Subjective performance refers to the perception and subjective feelings of senior managers toward their own hospital's performance. However, hospitals' performance cannot only be evaluated by medical expenditures of the NHI, and needs to include patients' own expenditures. Similarly to previous studies [19-21], this study refers to the balanced scorecard [22] and the recommendations of professionals on hospital performance measurements. This study uses four dimensions of the balanced scorecard, including organizational learning and growth, internal processes, customer perspective, and financial dimensions. Finally, 10 items were included to enable each hospital's senior supervisor to indicate the management team's satisfaction with the yearly operation of the hospital on a 10-point scale (1 "strongly disagree"; 10 "strongly agree"). These items were medical quality, employees' learning and growth, patients' and relatives' satisfaction, outpatient service personnel, emergency service personnel, hospitalization personnel, occupancy rate, income from customers' own expenditures, use of high-tech medical equipment, and overall medical income for the year.

\section{Control variables}

The critical control variables included in the study are ownership, evaluation level, and size of hospitals. From related research, ownership signifies that hospitals are divided into three categories, based on their ownership or profit share: public hospitals, private non-profit hospitals, and private for-profit hospitals [3, 4, 23-26]. Because ownership is a category variable, it is considered as a dummy variable. The evaluation level is based on the announcement of the Ministry of Health and Welfare. Similarly, the evaluation level of a hospital is also treated as a dummy variable. Organizational size is measured based on related research on hospitals [23, 24, 26]. Here, the variable is measured using the number of beds in a hospital, including acute beds, chronic beds, special beds, and observation beds. These organizational sizes are based on the number of beds registered on December 31, and the natural logarithms of these values are recorded for 2006, 2007, and 2008.

\section{Results}

According to Table 2, among the implementation requirements of each type of action, "procurement of new medical equipment" and "enhancement of medical quality" have the highest implementation requirements points (3.9), followed by "mergers and acquisitions" (3.8625), and "development of featured medical service with characteristics" (3.8417). Among the 21 action types, 11 are higher than the mean 3.5694, and are thus referred to as "strategic actions." Then, the other 10 types of actions are referred to as "tactical actions." It can be observed from Table 2 that the identified strategic actions conform to the definitions of Chen et al. [6], who argue that strategic actions need greater resource commitments.

Table 3 presents the numbers of competitive action types over a three-year period. The most frequent competitive action types used by hospital managers are service improvement/enhancement $(n=796)$, followed by delegation affairs unrelated to the NHI $(n=480)$ and cooperation with other hospitals in the same industry $(n=456)$. The correlation coefficients are presented in Table 4.

\section{Results of regression analysis using generalized estimating equation models}

Table 5 reveals the results of a hierarchical regression using generalized estimating equation (GEE) models. Model 1 is the result of the regression between the 
Table 2 Type of competitive actions of hospitals and the dimensions use to assess implementation requirements of action

\begin{tabular}{|c|c|c|}
\hline Competitive actions & $\begin{array}{l}\text { Implementation } \\
\text { requirements of } \\
\text { actions (mean) }\end{array}$ & $\begin{array}{l}\text { implementation } \\
\text { requirements of actions } \\
\text { dimensions }\end{array}$ \\
\hline $\begin{array}{l}\text { Procurement of new } \\
\text { medical equipment }\end{array}$ & 3.9000 & \multirow{21}{*}{$\begin{array}{l}\text { - High capital should be } \\
\text { invested when } \\
\text { executing the action. } \\
\text { - The management } \\
\text { should make significant } \\
\text { efforts when executing } \\
\text { the action. } \\
\text { - Personnel, system or } \\
\text { process should be } \\
\text { reconfigured when } \\
\text { executing the action. } \\
\text { - The support of external } \\
\text { stakeholders is required } \\
\text { when executing the } \\
\text { action. } \\
\text { - Senior supervisors } \\
\text { should announce the } \\
\text { execution of the action. } \\
\text { - The action should be } \\
\text { significantly reported in } \\
\text { the internal journals. } \\
\text { - Main stakeholders are } \\
\text { the targets for } \\
\text { responsibility and duty } \\
\text { in the execution of the } \\
\text { action. } \\
\text { - The equipment should } \\
\text { be reorganized when } \\
\text { executing the action. } \\
\text { - High level of cross- } \\
\text { department integration } \\
\text { is not required when } \\
\text { executing the action. } \\
\text { - After the execution of } \\
\text { the action, the levels of } \\
\text { the organizations and } \\
\text { authority should have } \\
\text { high level of } \\
\text { commitment. } \\
\text { - Senior supervisors } \\
\text { should approve the } \\
\text { execution of the action. } \\
\text { - Once the action is not } \\
\text { executed, the related } \\
\text { resources cannot be } \\
\text { transferred to other } \\
\text { actions. }\end{array}$} \\
\hline $\begin{array}{l}\text { Enhancement of } \\
\text { medical quality }\end{array}$ & 3.9000 & \\
\hline Merger and acquisition & 3.8625 & \\
\hline $\begin{array}{l}\text { Development of } \\
\text { featured medical } \\
\text { service }\end{array}$ & 3.8417 & \\
\hline $\begin{array}{l}\text { Development of } \\
\text { innovative medical } \\
\text { service }\end{array}$ & 3.8250 & \\
\hline $\begin{array}{l}\text { Expansion of service } \\
\text { areas }\end{array}$ & 3.7875 & \\
\hline $\begin{array}{l}\text { Development of } \\
\text { medical items upon } \\
\text { customers' } \\
\text { expenditure }\end{array}$ & 3.7333 & \\
\hline $\begin{array}{l}\text { Service improvement/ } \\
\text { enhancement }\end{array}$ & 3.6875 & \\
\hline $\begin{array}{l}\text { Change of } \\
\text { organizational } \\
\text { structure }\end{array}$ & 3.6292 & \\
\hline $\begin{array}{l}\text { Participation in } \\
\text { community service }\end{array}$ & 3.6125 & \\
\hline Alliance & 3.5917 & \\
\hline $\begin{array}{l}\text { Acquisition of fair } \\
\text { payment of medical } \\
\text { cost }\end{array}$ & 3.4958 & \\
\hline $\begin{array}{l}\text { Share of financial } \\
\text { responsibility }\end{array}$ & 3.4792 & \\
\hline $\begin{array}{l}\text { Different industry } \\
\text { cooperation }\end{array}$ & 3.4375 & \\
\hline $\begin{array}{l}\text { Change of cost } \\
\text { structure }\end{array}$ & 3.4208 & \\
\hline $\begin{array}{l}\text { Delegation affairs } \\
\text { unrelated to NHI }\end{array}$ & 3.3917 & \\
\hline $\begin{array}{l}\text { Medical business } \\
\text { outsourcing }\end{array}$ & 3.3542 & \\
\hline $\begin{array}{l}\text { Price cutting/ } \\
\text { promotion }\end{array}$ & 3.3083 & \\
\hline $\begin{array}{l}\text { Non-medical business } \\
\text { outsourcing }\end{array}$ & 3.2958 & \\
\hline $\begin{array}{l}\text { Same industry } \\
\text { cooperation }\end{array}$ & 3.2125 & \\
\hline $\begin{array}{l}\text { Bargaining of } \\
\text { procurement }\end{array}$ & 3.1917 & \\
\hline
\end{tabular}

${ }^{a}$ Respondents rated each dimension on five-point scale (1, very low; 5 , very high) for each competitive action. The index is mean

independent variables and subjective performance. Then, model 2 includes the control variables and independent variables. The result of the independent variables in relation to objective performance is presented in model 3. Lastly, the relationships between the control variables and independent variables, as well as their objective performance, are examined by including them in model 4 .

A hospital does not show better performance when it undertakes higher implementation requirements of actions. This means that higher implementation requirements result in a decrease in either the subjective $(\beta=$ $-20.920, p>0.1)$ or objective performance $(\beta=-0.417$, $p<0.01)$ of hospitals. The strategic orientation of actions has a positive relationship with the perception of a hospital's performance $(\beta=5.9890, p<0.01)$, but has no effect on objective performance $(\beta=-0.009, \quad p>0.1)$. Strategic actions are positively correlated with the perception of a hospital's performance. Action complexity has a positive relationship with both subjective $(\beta=$ $0.0272, p<0.01)$ and objective $(\beta=0.002, p<0.01)$ performance. Therefore, when hospitals adopt greater action complexity, this is expected to have a positive effect on both the subjective and objective performance.

\section{Discussion \\ Implementation requirements of actions}

Previous research argues that higher implementation requirements reduce the ability of competitors to respond and the speed of their responses [6]. Therefore, organizations undertake actions that result in a better performance. Actions require commitment from each level in the organization and certain implementation requirements, such as adjustments to the organizational structure and cooperation between teams. Certain actions, such as alliances or mergers and acquisitions, require more time and resources in order to integrate stakeholders and reorganize the organizational structure [6]. This makes it difficult to ascertain their effects on hospital performance, particularly over a short period. Here, no positive correlation is identified between subjective and objective performance when hospitals undertake actions with higher implementation requirements. Therefore, it is recommended that future research adopt a longitudinal design to follow the long-term effects of the implementation requirements of actions on hospitals.

\section{Strategic orientation of action}

Among the actions undertaken by organizations, a greater strategic orientation results in fewer responses by competitors because organizations commit to their actions, thus deterring competitive responses [27]. Moreover, the efficiency of strategic actions could be uncertain, even after a relatively long period [28]. Therefore, competitors respond after the uncertainty disappears, which further motivates firms to undertake strategic actions. 
Table 3 The number of competitive action type adopted by hospitals

\begin{tabular}{|c|c|c|c|c|c|c|c|c|}
\hline \multirow{2}{*}{$\begin{array}{l}\text { The number of competitive action } \\
\text { Competitive actions type }\end{array}$} & \multicolumn{3}{|c|}{ Medical centers } & \multirow{2}{*}{$\begin{array}{l}\text { Medical } \\
\text { centers } \\
3 \text { years } \\
\text { accumulation }\end{array}$} & \multicolumn{3}{|c|}{ Regional hospitals } & \multirow{2}{*}{$\begin{array}{l}\text { Regional } \\
\text { hospitals } \\
3 \text { years } \\
\text { accumulation }\end{array}$} \\
\hline & 2006 & 2007 & 2008 & & 2006 & 2007 & 2008 & \\
\hline Procurement of new medical equipment & 7 & 6 & 6 & 19 & 3 & 13 & 22 & 38 \\
\hline Enhancement of medical quality & 21 & 21 & 22 & 64 & 63 & 72 & 71 & 206 \\
\hline Merger and acquisition & 0 & 0 & 0 & 0 & 1 & 0 & 2 & 3 \\
\hline Development of featured medical service & 17 & 17 & 21 & 55 & 41 & 48 & 61 & 150 \\
\hline Development of innovative medical service & 30 & 32 & 38 & 100 & 51 & 87 & 100 & 238 \\
\hline Expansion of service areas & 5 & 5 & 7 & 17 & 9 & 10 & 13 & 32 \\
\hline Development of medical items upon customers' expenditure & 36 & 37 & 40 & 113 & 78 & 92 & 105 & 275 \\
\hline Service improvement/enhancement & 55 & 58 & 59 & 172 & 182 & 219 & 223 & 624 \\
\hline Change of organizational structure & 5 & 5 & 5 & 15 & 14 & 14 & 16 & 44 \\
\hline Participation in community service & 17 & 17 & 17 & 51 & 57 & 67 & 69 & 193 \\
\hline Alliance & 0 & 0 & 0 & 0 & 30 & 33 & 36 & 99 \\
\hline Acquisition of fair payment of medical cost & 20 & 20 & 20 & 60 & 58 & 65 & 70 & 193 \\
\hline Share of financial responsibility & 7 & 7 & 6 & 20 & 19 & 19 & 21 & 59 \\
\hline Different industry cooperation & 4 & 4 & 8 & 16 & 11 & 18 & 34 & 63 \\
\hline Change of cost structure & 32 & 32 & 32 & 96 & 59 & 64 & 83 & 206 \\
\hline Delegation affairs unrelated to $\mathrm{NHI}$ & 42 & 42 & 42 & 126 & 100 & 127 & 127 & 354 \\
\hline Medical business outsourcing & 4 & 4 & 4 & 12 & 12 & 13 & 14 & 39 \\
\hline Price cutting/promotion & 16 & 20 & 21 & 57 & 40 & 59 & 68 & 167 \\
\hline Non-medical business outsourcing & 17 & 16 & 17 & 50 & 52 & 59 & 60 & 171 \\
\hline Same industry cooperation & 38 & 38 & 38 & 114 & 101 & 119 & 122 & 342 \\
\hline Bargaining of procurement & 20 & 20 & 21 & 61 & 63 & 68 & 68 & 199 \\
\hline Total & 393 & 401 & 424 & 1218 & 1044 & 1266 & 1385 & 3695 \\
\hline
\end{tabular}

Previous research has argued that strategic actions incur fewer and slower responses, resulting in a positive relationship between this kind of action and the benefits [6, 11]. Although the results of this study support the positive correlation between strategic action and the perception of a hospital's performance, there is no positive correlation between these actions and objective performance.
The latter finding may be the result of the objective performance measurement, which uses the medical fees hospitals apply from the NHIA. However, some types of strategic actions, such as mergers and acquisitions, alliances, expansions of service areas, and the development of new medical services (e.g., micro cosmetic surgery, weight loss, etc.) should yield greater benefits to hospitals

Table 4 Pearson correlation analysis

\begin{tabular}{|c|c|c|c|c|c|c|c|c|}
\hline Name of variables & 1 & 2 & 3 & 4 & 5 & 6 & 7 & 8 \\
\hline \multicolumn{9}{|l|}{1 Private non-profit hospital } \\
\hline 2 Private for-profit hospitals & $-0.535^{* *}$ & & & & & & & \\
\hline 3 Regional hospital & $-0.357^{* *}$ & $0.327^{*}$ & & & & & & \\
\hline 4 Organizational size & -0.049 & -0.050 & $-0.654^{* *}$ & & & & & \\
\hline 5 Implementation requirements & 0.188 & -0.220 & $-0.378^{* *}$ & $0.489^{* *}$ & & & & \\
\hline 6 Strategic orientation & $-0.347^{* *}$ & 0.248 & -0.003 & $0.351^{* *}$ & $0.295^{*}$ & & & \\
\hline 7 Action complexity & -0.140 & 0.089 & $-0.386^{* *}$ & $0.560^{* *}$ & $0.497^{* *}$ & $0.593^{* *}$ & & \\
\hline 8 Perception performance & $-0.420^{* *}$ & 0.135 & -0.101 & $0.351^{* *}$ & $0.625^{* *}$ & $0.592^{* *}$ & 0.088 & \\
\hline 9 Objective performance & 0.041 & 0.097 & $-0.721^{* *}$ & $0.803^{* *}$ & 0.253 & $0.647^{* *}$ & 0.242 & $0.377^{* *}$ \\
\hline
\end{tabular}


Table 5 Hierarchical regression in Generalized Estimating Equation Models analytical result of hospital performance

\begin{tabular}{|c|c|c|c|c|c|c|c|c|c|c|c|c|}
\hline \multicolumn{13}{|c|}{ Dependent variables: management performance } \\
\hline \multirow[b]{2}{*}{ Variables } & \multicolumn{3}{|c|}{$\begin{array}{l}\text { Model } 1 \\
\text { interviewee perception } \\
\text { performance }\end{array}$} & \multicolumn{3}{|c|}{$\begin{array}{l}\text { Model } 2 \\
\text { interviewee perception } \\
\text { performance }\end{array}$} & \multicolumn{3}{|c|}{$\begin{array}{l}\text { Model } 3 \\
\text { Objective performance }\end{array}$} & \multicolumn{3}{|c|}{$\begin{array}{l}\text { Model } 4 \\
\text { Objective performance }\end{array}$} \\
\hline & B1 & Std.Error1 & Sig. & B2 & Std.Error2 & Sig. & B3 & Std.Error3 & Sig. & B4 & Std.Error4 & Sig. \\
\hline \multicolumn{13}{|l|}{ Independent variables } \\
\hline Implementation requirements & -20.281 & 13.9198 & & -20.920 & 15.8432 & & -0.121 & 0.2733 & & -0.417 & 0.1372 & *** \\
\hline Strategic orientation & 24.126 & 4.7518 & $* * *$ & 20.745 & 5.9890 & $* * *$ & -0.145 & 0.2885 & & -0.009 & 0.2018 & \\
\hline Action complexity & 0.086 & 0.0273 & $* * *$ & 0.079 & 0.0272 & $* * *$ & 0.003 & 0.0005 & $* * *$ & 0.002 & 0.0004 & *** \\
\hline \multicolumn{13}{|l|}{ Control variables } \\
\hline Private non-profit hospital & & & & -9.751 & 6.3849 & & & & & 0.043 & 0.0673 & \\
\hline Private for-profit hospitals & & & & -7.451 & 5.9564 & & & & & 0.169 & 0.0757 & $* *$ \\
\hline Regional hospital & & & & 1.257 & 8.8418 & & & & & -0.317 & 0.1262 & $* *$ \\
\hline Organizational size & & & & 0.005 & 0.0074 & & & & & 0.000 & 8.5350 & $* * *$ \\
\hline
\end{tabular}

because they do not include an NHI payment or they are paid for by customers. Therefore, significant effects from objective performance cannot be observed.

\section{Action complexity}

Several works argue that when organizations undertake more types of actions, they are more offensive than when using simple strategic actions, thus resulting in better performance $[14,15,29]$. Our results support that hospitals perform better as the action complexity increases. For example, myopia laser surgery, which many hospitals offer, differs in terms of patient satisfaction. Furthermore, many complex procedures, such as estimations before surgery, the stability of equipment, and the skills of surgeons entail long-term experience, customized surgery, and femtosecond non-knife cutting laser instruments. These factors make it difficult for hospitals to determine the results of these actions. Therefore, in order to perform better, competitors should not respond to the types of strategy actions that prompt hospitals to undertake these actions.

\section{Conclusions}

Today, the global hospital management domain is highly competitive, and hospitals incur relative costs in response to competitive actions. Hospitals can undertake multiple actions when faced with environmental challenges [30]. This study provides hospitals with a concrete action type using competitive dynamics, offering management a different perspective from which to investigate their actions, as well as the implications of such actions. Hospitals should apply a competitive dynamic strategy to examine their own actions as well as those of their competitors. The healthcare industry should determine opportunities under the global budget policy by reducing medical payments under health insurance, given the medical regulations and generally compliant patients. Managers of hospitals should re-examine their strategic actions, and determine how other hospitals adopt appropriate strategies in order to survive in the competitive market.

\section{Limitations and suggestions for future research}

We collected information on the action types and perceptions of hospitals' performance for a three-year period using questionnaires. However, respondents do always clearly remember past actions in detail, which could cause a bias in the research results. In addition, although we included a category for "other" action types in the questionnaires, some actions may not be considered, or could be missed. Here, examples include items that belong to non-medical business outsourcing, such as waste disposal, electronic engineering, sludge disposal, public works, and air conditioning. In addition, the small sample size limits the generalizability to other fields.

Competitive interaction is a complicated and dynamic process [10]. Based on the results of the relationship between action characteristics and hospital performance, this study suggests that future research determine additional types of actions for each year and employ longitudinal data. Furthermore, future work should classify the 21 types of actions based on their customer orientation. In addition, the complex actions of hospitals change with the progress of technology. Lastly, researchers could collect data on the income generated by hospitals, including customers' own expenses and registration fees, in order to determine why strategic orientation has no effect on objective performance. 


\section{Abbreviations}

AMC: Awareness-motivation-capability; MHW: Ministry of Health and Welfare: $\mathrm{NHI}$ : National Health Insurance; NHIA: National Health Insurance Administration

\section{Acknowledgements}

The authors would like to thank all the respondents who participated in this study.

\section{Funding}

No funding.

Availability of data and materials

Not applicable.

\section{Authors' contributions}

$\mathrm{CHC}$ designed the study, performed the analyses, and wrote the manuscript. YCC and YT reviewed, edited, and approved the final manuscript. All authors have read and approved the final version of this manuscript.

\section{Authors' information}

Chuan-Hui Chang is a doctoral candidate in the Department of Business Administration, National Chung Hsing University in Taiwan. She is also a specialist in the Central Division, National Health Insurance Administration in Taiwan. Yu-Ching Chiao, PhD, is a Professor of Business Administration at the National Chung Hsing University, Taiwan, R.O.C. His research and teaching interests include international business management and global competitive strategy. His publications have appeared in the Small Business Economics, Journal of Business Research, Journal of World Business, International Marketing Review, Journal of Applied Psychology, International Journal of Shipping and Transport Logistics, Management International Review, European Journal of International Management, IEEE Transactions on Engineering Management, International Journal of Technology Management, among others.

Dr. Yafang Tsai is a Professor in the Department of Health Policy and Management of Chung Shan Medical University in Taiwan and is an advisor to the Department of Medical Management of Chung Shan Medical University Hospital. Dr. Tsai is primarily involved in health care management (particularly human resources management), health care marketing, organizational learning, and internal marketing. She has published works in international journals, including the Journal of Advanced Nursing, Journal of Clinical Nursing, BMC Health Services Research, International Nursing Reviewer, Industrial Marketing Management, and Total Quality Management \& Business Excellence. Dr. Tsai has previously worked in the administration department of a medical center in Taiwan.

\section{Ethics approval and consent to participate}

The dataset we used was obtained from the open website of National Health Insurance Administration. This research project was approved by $\mathrm{NHIA}$ in term of ethical concerns.

\section{Consent for publication}

Not applicable.

\section{Competing interests}

The authors declare that they have no competing interests. This research received no specific grant from any funding agency in the public, commercial, or not-for-profit sectors.

\section{Publisher's Note}

Springer Nature remains neutral with regard to jurisdictional claims in published maps and institutional affiliations.

\section{Author details}

'Department of Business Administration, National Chung Hsing University, Taichung, Taiwan. ${ }^{2}$ Central Division, National Health Insurance Administration Ministry of Health and Welfare, Taichung, Taiwan. ${ }^{3}$ Department of Health Policy and Management, Chung Shan Medical University, Taichung, Taiwan. ${ }^{4}$ Department of Medical Management, Chung Shan Medical University Hospital, Taichung, Taiwan.
Received: 30 November 2016 Accepted: 7 November 2017

Published online: 21 November 2017

\section{References}

1. Mukamel DB, Zwanziger J, Bamezai A. Hospital competition, resource allocation and quality of care. BMC Health Serv Res. 2002:2:1-9.

2. Chen CC, Cheng SH. Measuring competition in the health care market: starting with market area definition and competition indicators. Taiwan J Public Hlth. 2008:27(4):292-300.

3. Jiang HJ, Friedman B, Begun JW. Sustaining and improving hospital performance: the effects of organizational and market factors. Health Care Manag Rev. 2006;31:188-96.

4. Trinh $\mathrm{HQ}$, Begun JW, Luke RD. Hospital service duplication: evidence on the medical arms race. Health Care Manag Rev. 2008;33:192-202.

5. Van Dijk CE, Venema B, De Jong JD, De Bakker DH. Market competition and price of disease management programmes: an observational study. BMC Health Serv Res. 2014;14:1-7.

6. Chen MJ, Smith KG, Grimm CM. Action characteristics as predicts of competitive response. Manag Sci. 1992;38(3):439-55.

7. Chen MJ. Competitor analysis and interfirm rivalry: toward a theoretical integration. Acad Manag Rev. 1996;21(1):100-34.

8. Kiesler S, Sproull L. Managerial response to changing environments: perspectives on problem sensing from social cognition. Adm Sci Q. 1982; 27(4):548-70.

9. Livengood RS, Reger RK. That's our turf! Identity domains and competitive dynamics. Acad Manag Rev. 2010;35(1):48-66.

10. Chen MJ, MacMillan IC. Nonresponse and delayed response to competitive moves: the roles of competitor dependence and action irreversibility. Acad Manag J. 1992;35(3):539-70.

11. Smith KG, Grimm CM, Gannon MJ, Chen MJ. Organizational information processing, competitive responses, and performance in the U.S. domestic airline industry. Acad Manag J. 1991;34(1):60-85.

12. Knight K, McDaniel RR. Organizations: an information systems perspective. Belmont. CA: Wadsworth Publishing; 1979

13. Miller D, Chen MJ. Sources and consequences of competitive inertia: a study of the U.S. air industry. Adm Sci Q. 1994;39(1):1-23.

14. D'Aveni RA. Hypercompetition: managing the dynamics of strategic maneuvering. New York: Free Press; 1994

15. Miller D, Chen MJ. The simplicity of competitive repertoires: an empirical analysis. Strategic Manage J. 1996;17(6):419-39

16. Chiang $\mathrm{TL}$, Wen $\mathrm{YP}$, Hsieh $\mathrm{CH}$. The impact of the supply of physician manpower and hospital beds on the total payments of $\mathrm{NHI}$. Commissioned Research Programs of Executive by the Ministry of Health and Welfare; 2001.

17. Smith KG, Ferrier WJ, Ndofor $\mathrm{H}$. Competitive dynamics research: critique and future directions. London: Blackwell Publishers; 2001.

18. National Health Insurance Administration, Ministry of Health and Welfare. Hospital monthly reporting points exposed. https://www.nhi.gov.tw/ Content_List.aspx?n=FD1225865A44D665\&topn=CDA985A80C0DE710. Accessed 10 Feb 2010

19. Wick AM, Clair LS. Competing values in healthcare: balancing the (un)balanced scorecard. J Healthc Manag. 2007;52(5):309-23.

20. Griffith JR, Alexander JA. Measuring comparative hospital performance. J Healthc Manag. 2002;47(1):41-57.

21. Yang MC, Tung YC. Using path analysis to examine causal relationships among balanced scorecard performance indicators for general hospitals: the case of a public hospital system in Taiwan. Health Care Manag Rev. 2006;31:280-8

22. Kaplan RS, Norton D. The balanced scorecard: measures that drive performance. Harvard Bus Rev. 1992;70(1):71-9.

23. McKay NL, Gapenski LC. Nonpatient revenues in hospitals. Health Care Manag Rev. 2009;34:234-41.

24. Tiemann O, Schreyogg J. Effects of ownership on hospital efficiency in Germany. Chicago: Paper presented at the annual meeting of the Academy of Management; 2009.

25. Coyne JS, Richards MT, Short R, Shultz K, Singh SG. Hospital cost and efficiency: do hospital size and ownership type really matter? J Healthc Manag. 2009:54(3):163-76.

26. Trinh HQ, Begun JW, Luke RD. Better to receive than to give? interorganizational service arrangements and hospital performance. Health Care Manage R. 2010;35(1):88-97. 
27. Porter ME. Competitive strategy: techniques for analysis industries and competitors. New York: Free Press; 1980.

28. Wernerfelt B. Karnani. A competitive strategy under uncertainty. Strategic Manage J. 1987;8(2):187-94.

29. Ferrier WJ, Smith KG, Grimm CM. The role of competitive action in market share erosion and industry dethronement: a study of industry leaders and challengers. Acad Manag J. 1999;42:372-88.

30. Hsieh HM, Clement DG, Bazzoli GJ. Impacts of market and organizational characteristics on hospital efficiency and uncompensated care. Health Care Manag Rev. 2010;35:77-87.

Submit your next manuscript to BioMed Central and we will help you at every step:

- We accept pre-submission inquiries

- Our selector tool helps you to find the most relevant journal

- We provide round the clock customer support

- Convenient online submission

- Thorough peer review

- Inclusion in PubMed and all major indexing services

- Maximum visibility for your research

Submit your manuscript at www.biomedcentral.com/submit
Biomed Central 